\title{
AUTOC-AR: A CAR DESIGN AND SPECIFICATION AS A WORK SAFETY GUIDE BASED ON AUGMENTED REALITY TECHNOLOGY
}

\author{
Aulia Akhrian Syahidi ${ }^{1}$, Subandi ${ }^{2}$, and Amran Mohamed ${ }^{3}$ \\ ${ }^{1}$ Chair of Interactive Media, Game, and Mobile Technologies Research Group, Politeknik Negeri Banjarmasin, Indonesia \\ ${ }^{2} \mathrm{Head}$ of Informatics Engineering Study Program, Politeknik Negeri Banjarmasin, Indonesia \\ ${ }^{3}$ Director of Research and Technology Development, EON Reality PTE LTD, Singapore \\ E-mail: aakhriansyahidi@poliban.ac.id
}

\begin{abstract}
The development of Augmented Reality (AR) technology until now continues to increase. Utilization of AR has been used in various aspects of life, including aspects of education, is no exception for automotive engineering education. In recent years, a variety of ideas and the latest innovations about automotive by utilizing AR technology began to boom, especially in the area of car design aimed at car production companies. At the car production stage, human resources skilled in understanding the design and specifications of car features are required. The seeds of educated human resources start from vocational students in automotive engineering expertise programs. This study aims to develop and implement an application called AUTOC-AR that functions to help and facilitate students in learning automotive engineering skills in vocational schools and supporting safety in the workplace. The research methodology consisted of a literature review and excavation of problems and needs, solution recommendations, application development, testing, results and discussion, conclusions and future work. The Extreme Programming (XP) model was used as a development method. Marker-based tracking was used as a detection approach. As many as 25 students as end-users were involved to use AUTOC-AR. The result is that all features in the AUTOC-AR application function properly based on the expected specifications. Non-functional testing has been carried out by adopting a user experience approach with a final average value of 4.83 with a percentage of $96.6 \%$.
\end{abstract}

Keywords: augmented reality, automotive engineering, user experience

\section{INTRODUCTION}

Over time, the increasingly dynamic development of technology has made all aspects of human life inevitable with the use of technology. No exception in the aspect of education. Technological development, especially in the field of multimedia, namely Augmented Reality technology can maximize the increase in various ideas in learning innovation. Azuma [1] puts forward a theory about Augmented Reality (AR), namely technology that combines virtual objects into an actual environment and then visualizes these virtual objects directly into the actual world. Virtual objects are the basic forms of the original objects visualized through media aids. This is what makes AR technology has a usefulness as a tool in helping the perception and interaction of its use in the real world. Feng et al. [2] state that in general, the focus in the development of AR technology consists of tracking technology, visualization technology, and interaction technology.

Tolle et al. [3] state that the presence of AR can enrich the real world by adding digital information and media such as 3D objects and videos in real-time both on Smartphone cameras, tablets, and others. Syahidi et al. [4] mentioned that AR technology is very rich in interaction and magical elements so that it makes the users feel something extraordinary and interesting to use. Gladston \& Duraisamy [5] state that AR is a sophisticated technology based on computer vision to integrate $\mathrm{AR}$ with the real world, AR technology is increasing in its utilization and use both in industry and academia. From the perspective of education according to Syahidi et al. [6] can save funding in terms of learning media, simply installing the application on a smartphone without the need to buy learning media equipment that tends to be inefficient in terms of place and even time. 
These points led to new ideas to develop AR technology towards automotive engineering education, which in this case is to facilitate the learning of automotive engineering in recognizing and understanding the design and specification of features in cars. Students do not need to be directly at the place of practice to know the specifications of car features; it also supports the concept of work safety. The initial condition is that automotive engineering students are directed towards the use of textbooks and direct practice, but this is considered to be inefficient, especially when students directly practice meaning safety at work is not obeyed.

The latest issue in the use of $A R$ technology in automotive engineering states that the presence of AR technology for the automotive world is likely to increase productivity and efficiency of car production. It is widely used in designing cars for the sustainability of car manufacturers. Not only in terms of design, AR technology for cars are also directed towards recommending the appointment of direction or lane detection on highway trajectories and other information. From several issues, the use of AR is intended for the team of car production companies. The team of car production companies must indirectly have human resources who know and understand the theories and practices in the world of automotive engineering, especially in the design and specifications of car features. The beginning of the creation of educated human resources through vocational schools for automotive engineering skills, there is a need to provide good education and the approach and use of the latest technology to be able to face the challenges and demands of work.

Ideas in learning innovation in utilizing other AR technologies as has been done by Syahidi et al. [4] who designed and developed the BandoAR application for learning Banjar Languages and recommended applications to facilitate local and foreign tourists to understand Banjar Language using AR technology with a markerless method. Then
Syahidi et al. [6] designed and developed a learning application for animal and fruit recognition called AR-Child, which was accompanied by pronunciation and naming based on AR technology with marker-based tracking methods aimed at early childhood. According to Herlandy et al. [7], the use and application of AR in implementing the learning process, of course, can be a solution so that learning is more interesting, especially when implemented in productive subjects in vocational education, especially in Indonesia. Next from Suryanto et al. [8] who developed an AR-based of lathe machine introduction learning media to make it easier for vocational students to understand the parts of a lathe machine, students tend to be helped by the AR application and can be applied in the vocational learning process. According to Ismail et al.[9] states that by applying AR to the learning process can improve the visualization side and reduce cognitive load, creating a learning experience that is more engaging students' interests and a safe learning environment.

From some of the research that has been done by researchers who utilize the advances in AR technology and are based on needs and problem findings. Thus the present study recommends the development and implementation of design applications and feature specifications on AR technology-based cars with a marker-based tracking method to help and facilitate students in learning automotive engineering expertise programs at vocational high schools.

\section{METHOD}

The method in this study consists of six stages in general, which are shown in Figure 1. The research method consisted of carrying out a literature review to several sources by looking at the relevance of the proposed topic, exploring problems and needs by adjusting the results of the literature review, recommending solutions, and developing applications using the Extreme Programming (XP) development model. The 
next steps were conducting functional and nonfunctional testing, explaining the results and discussing the study that has been carried out. The last step was concluding and recommended works for future development. The Extreme Programming development model of Pressman [10] is used thus the implementation of development is carried out quickly, without much informal documentation and being sensitive to all changes of users' needs by handling them quickly and flexibly.

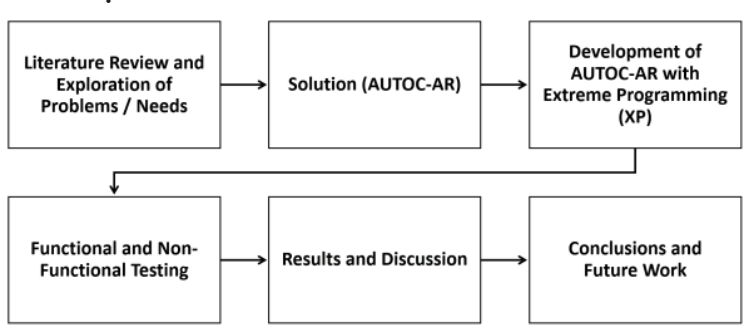

Figure 1. Research Methodology

Furthermore, the method in AR technology, where AR provides an overview to users about the merging of the real world with virtual space viewed from the same place. There are two very popular AR methods, marker-based tracking, and markerless. Markerbased tracking is a special marker that is created like a barcode or black frame, QR code, and printed AR marker, which has a pattern that will be read by a computer via a webcam or camera that has been connected to the computer [11]. While the markerless method is a marker that is directly related to natural objects, namely AR markers that are printed naturally and markers of life that exist in the actual environment [12]. In this study, the markerbased tracking method is shown in Figure 2. Based on Figure 2, the flow chart of the markerbased tracking method [6] is very simple, but it must ensure that the patterns of the markers have been loaded in the database. Therefore, the marker tracking process can run effectively, and $3 \mathrm{D}$ objects must be visualized when tracking is successful.

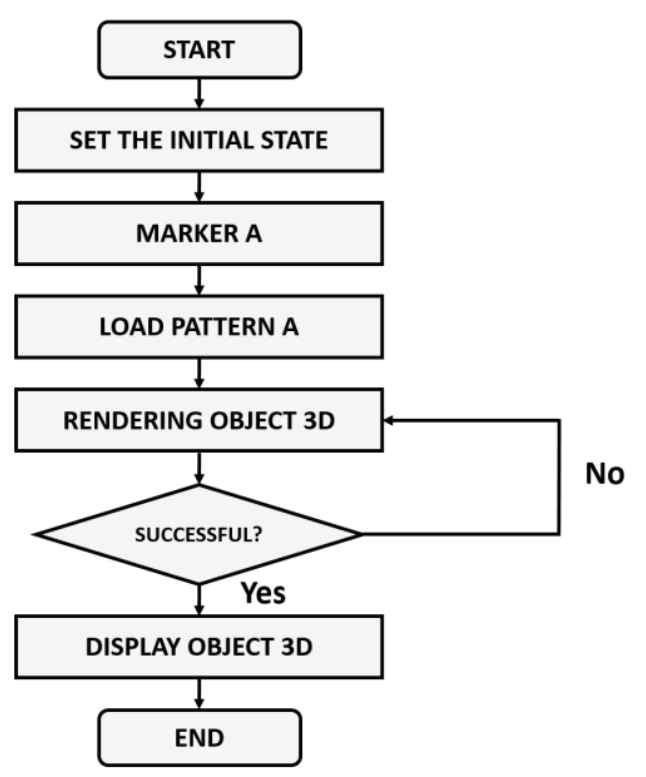

Figure 2. Marker-Based Tracking Method

The Extreme Programming model is used to develop the AUTOC-AR application; XP is one of the agile development models that has a fast process. The Extreme Programming methodology has four phases of performance namely planning, design, coding, and testing [10]. The planning stage is an activity to listen and gather information in the form of exploring needs and problems. The design phase strictly follows the principle as simple as possible, compared to complicated designs; simple designs tend to be preferred. The coding phase is to create AUTOC-AR application architecture through the coding process, also done refactoring. For architecture, the coding process is shown in Figure 3.

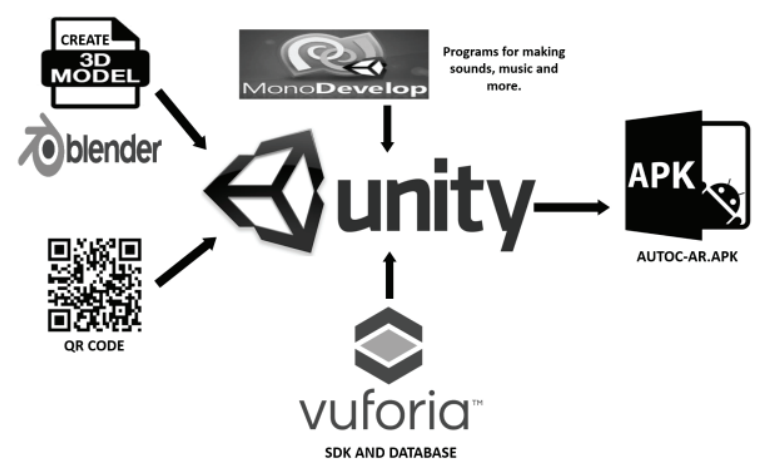

Figure 3. Architecture in the Coding Process 
The architecture in the coding process presented in Figure 3, is a process for creating applications using software including Unity, Blender, Vuforia SDK, and MonoDevelop. The next is the testing phase which is making unit tests (one of the main keys of the XP development method). Unit tests were developed using black-box testing adapted from Murnane \& Reed [12], Nidhra [13], and Steegmans et al. [14].

Subsequent testing is from the perspective of success on users' experience in using the application. User experience (UX) according to Norman in Allanwood \& Beare [15] confirms that in the current era it is not enough to only create applications that can function properly and can be used, but an application is also required to bring a pleasant impression to its users. The benefits of UX itself include providing convenience for users, increasing users' confidence, the level of user trust is greatly influenced by the ability (performance) shown by the application and all the features of the service provided to help solve user problems, and from the business side with a good UX trusted able to increase the number of users.

To measure users' experience using the users' experience questionnaire adapted from Laugwitz et al. [16], Cota et al. [17], Schrepp et al. [18], and Schrepp [19] who suggested that to measure users' experience, when end users use the product quickly and simply, it is used the UEQ (User Experience Questionnaire) with the assessment of answers in the form of Likert Scale of 5 to 1 . The scale was categorized as Very Strongly Agree, Strongly Agree, Agree, Disagree, and Strongly Disagree. The concept of the User Experience Questionnaire is presented in Figure 4.

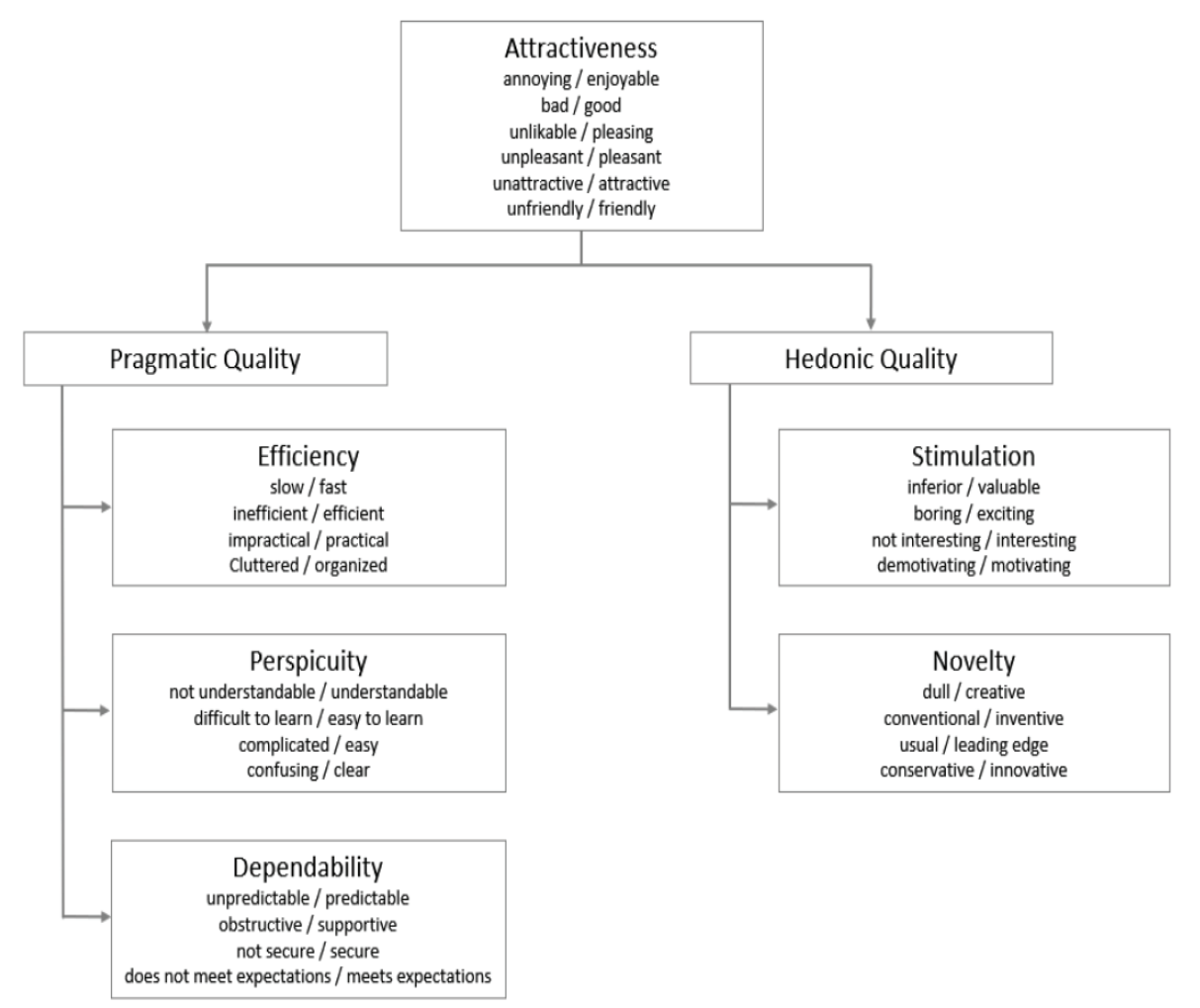

Figure 4. Scale Assumptions and Concepts of User Experience Questionnaire

Based on Figure 4, the User Experience Questionnaire states that the main aspects of the assessment consists of attractiveness, efficiency, perspicuity, dependability, stimulation, and novelty. Attractiveness is a dimension of pure valence. Perspicuity, 
efficiency, and dependability are pragmatic quality aspects (directed at the goal of the direct user experience aspect), whereas stimulation and novelty are hedonic quality aspects (not directed at the hedonic quality aspect) the purpose of users' experience, but aiming for the effect and recommendations/future work of the product being assessed).

\section{RESULTS AND DISCUSSION}

The design of the AUTOC-AR application will be developed. Before the design phase, the planning phase must be carried out by listening and gathering information in the form of exploring the needs of stakeholders, namely vocational teachers, so that the technical members of the XP team can understand the business context of the application, its functions, and what results expected from the AUTOC-AR application. In principle, making the AUTOC-AR application is made as simple as possible to make it easier to use.

Besides, the coding phase stated for application development is starting with creating a car object using the Blender application. The next is preparing a marker, so that later when the AR camera is directed, then a $3 \mathrm{D}$ object appears. The marker in this study is a barcode printed on paper measuring $10 \mathrm{~cm} \mathrm{x}$ $10 \mathrm{~cm}$. To make AR needed Unity software, Vuforia SDK or Database, and MonoDevelop which has also been included in Unity. The results of this phase are the user interface shown in Figure 5 and 6.

Figure 5 and 6 shows the AUTOC-AR application interface that has simulated its use. The AR camera has successfully detected so that it can bring up 3D car objects. Then when the AR camera is directed slowly to the parts on the car's 3D object, the user will be presented with a feature name along with the theory and application of the car's design.

Furthermore, black-box testing was performed to examine whether all provided features can function as expected based on functional requirements. This test observed the results of execution through test data and functional inspection software presented in Table 1. Table 1 shows that all features work and function by system expectations. Therefore, the AUTOC-AR application can be used by end-users with all the functions that run perfectly. The lighting, position and angle, the distance between the marker and the AR camera are very influential when tracking the marker.

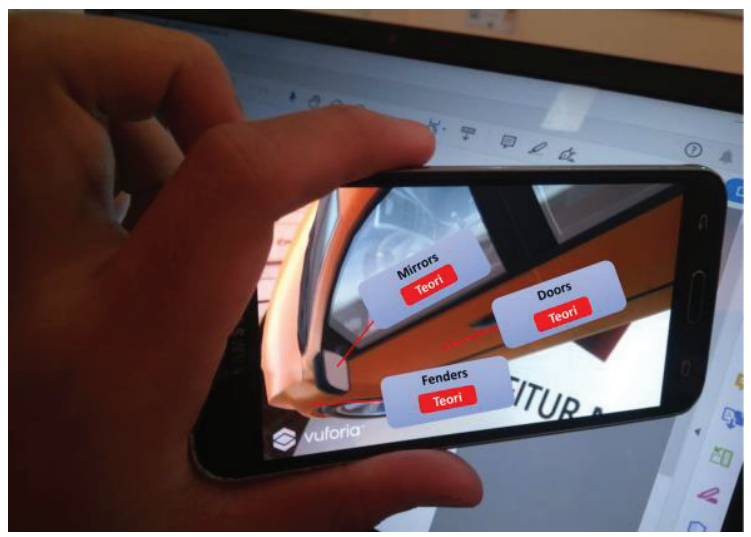

Figure 5. AUTOC-AR Simulation and Interaction (Outside the Car)

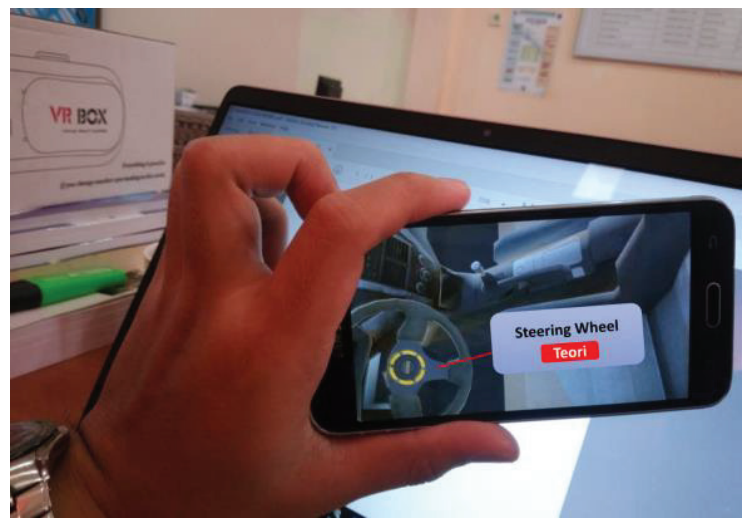

Figure 6. AUTOC-AR Simulation and Interaction (Inside the Car)

The users look very enthusiastic when trying to use the AUTOC-AR application in the learning class. Moural \& Oritsland [20] revealed that when users first use AR or VRbased applications indirectly tend to be highly motivated and comfortable. Early simulations users are required to install the AUTOC-AR application on their respective smartphones, they tend to be very interested in learning to 
recognize and understand the design and specifications of the features of the car. The teachers also give direction that this application can work safely before students practice it in the actual condition of the car.

\begin{tabular}{|c|c|c|c|}
\hline ID & Fitur (Input) & Expected results & Output \\
\hline AR1 & $\begin{array}{l}\text { Main Menu } \\
\text { Page }\end{array}$ & $\begin{array}{l}\text { Displays the main } \\
\text { menu page }\end{array}$ & OK \\
\hline AR2 & $\begin{array}{l}\text { Usage } \\
\text { Instructions } \\
\text { Page }\end{array}$ & $\begin{array}{l}\text { Display the usage } \\
\text { instructions page }\end{array}$ & OK \\
\hline AR3 & $\begin{array}{l}\text { AR Camera } \\
\text { Page }\end{array}$ & $\begin{array}{l}\text { Displays the activity } \\
\text { of the AR detection } \\
\text { camera }\end{array}$ & OK \\
\hline AR4 & Play Button & $\begin{array}{l}\text { Displays the AR } \\
\text { detection camera } \\
\text { page }\end{array}$ & OK \\
\hline AR5 & Exit Button & $\begin{array}{l}\text { Exit the application in } \\
\text { full }\end{array}$ & OK \\
\hline AR6 & $\begin{array}{l}\text { Guide } \\
\text { Button }\end{array}$ & $\begin{array}{l}\text { Display the usage } \\
\text { instructions page }\end{array}$ & OK \\
\hline AR7 & AR Object & $\begin{array}{l}\text { Displays AR objects } \\
\text { according to markers } \\
\text { in the database }\end{array}$ & OK \\
\hline AR8 & $\begin{array}{l}\text { AR Chassis } \\
\text { Component } \\
\text { Information }\end{array}$ & $\begin{array}{l}\text { Displays information } \\
\text { on the chassis } \\
\text { components that } \\
\text { accompany AR } \\
\text { objects that appear } \\
\text { (theory and their } \\
\text { application) }\end{array}$ & OK \\
\hline
\end{tabular}

The next test is in the form of users' experience consisting of 8 questions from 6 main aspects. A total of 25 end users from one of the vocational automotive engineering expertise programs were involved to evaluate the AUTOC-AR application by filling out an online user questionnaire. Table 2 presents the result of the respondents' responses.

Based on Table 2, the highest score is the aspect of the attractiveness of the AUTOC-AR application which has an average score of 5 with a percentage of $100 \%$. The users also strongly suggest that the interface and visualization of the AUTOC-AR are attractive with an average score of 5 and a percentage of
$100 \%$. Furthermore, the users strongly agree that the AUTOC-AR application is innovative and creative.

Table 2. Users' Experience Questionnaire Results

\begin{tabular}{|c|c|c|c|}
\hline No. & Aspects & Questions & $\begin{array}{l}\text { Average } \\
\text { Value }\end{array}$ \\
\hline 1 & Attractiveness & $\begin{array}{l}\text { Do users like the } \\
\text { AUTOC-AR } \\
\text { application? }\end{array}$ & 5 \\
\hline 2 & Perspicuity & $\begin{array}{l}\text { Is it easy to get to } \\
\text { know the AUTOC- } \\
\text { AR application? }\end{array}$ & 4.36 \\
\hline 3 & Perspicuity & $\begin{array}{l}\text { Is it easy to learn } \\
\text { how to use the } \\
\text { AUTOC-AR } \\
\text { application? }\end{array}$ & 4.88 \\
\hline 4 & Efficiency & $\begin{array}{l}\text { Can users use this } \\
\text { application as a } \\
\text { learning media in } \\
\text { the introduction of } \\
\text { car design and } \\
\text { feature } \\
\text { specifications? }\end{array}$ & 4.68 \\
\hline 5 & Dependability & $\begin{array}{l}\text { Do users feel they } \\
\text { can control the } \\
\text { interaction of the } \\
\text { AUTOC-AR } \\
\text { application? }\end{array}$ & 4.84 \\
\hline 6 & Stimulation & $\begin{array}{l}\text { Is the interface and } \\
\text { visualization of the } \\
\text { AUTOC-AR app } \\
\text { interesting? }\end{array}$ & 5 \\
\hline 7 & Stimulation & $\begin{array}{l}\text { Can it motivate } \\
\text { users to use } \\
\text { AUTOC-AR as a } \\
\text { learning media } \\
\text { application for } \\
\text { introducing car } \\
\text { design and feature } \\
\text { specifications? }\end{array}$ & 4.88 \\
\hline 8 & Novelty & $\begin{array}{l}\text { Is the AUTOC-AR } \\
\text { application } \\
\text { innovative and } \\
\text { creative? }\end{array}$ & 5 \\
\hline \multicolumn{3}{|c|}{ Total Overall Average Value } & 4.83 \\
\hline
\end{tabular}

The ease and motivation in using the application both achieve the average scores of 4.88 with a percentage of 97.6. The use of the AUTOC-AR application as a learning media application is for the introduction of design and feature specifications in the car. 
The users strongly agree that they feel they can control all interactions presented by the AUTOC-AR application with an average score of 4.84 with a percentage of $96.8 \%$. The average score of 4.68 with the percentage of $93.6 \%$ is achieved by the statement that the user can use the AUTOC-AR application as a learning media application for the introduction of design and feature specifications on the car.

The lowest score is obtained by the statement that the users find it easy to get to know the AUTOC-AR application which has an average score of 4.36 with a percentage of $87.2 \%$. The total average score of the results from the user experience questionnaire is 4.83 with a percentage of $96.6 \%$, which can be ascertained that the AUTOC-AR application has adapted the user experience approach of interaction and visualization of the interface.

In supporting work safety, with the application of AUTOC-AR, productive teachers have assessed that the application can be used in the productive learning process in automotive engineering programs on material design and car feature specifications. In the concept of work safety, one of which is to make an introduction to the equipment both functions, ways of working, and safety in its use. AUTOC-AR application is directly conceptualized as the concept of work safety.

The existence of learning media by utilizing AR technology such as AUTOC-AR greatly facilitates students in learning, supports work efficiency, and provides full support to vocational teachers to make innovations in learning. Especially in the $21^{\text {st }}$-century learning innovation is very important especially to welcome education era 5.0 [21].

\section{CONCLUSION}

Based on the results of the study, the AUTOC-AR application facilitates vocational students of automotive engineering expertise programs to learn and recognize the design and specification of features on cars. Functional testing has also been carried out with the result that all the features of the AUTOC-AR application meet the expected specifications. Non-functional testing with users' experience approaches using users' experience questionnaires obtained the total average score of 4.83 with a percentage of $96.6 \%$. It indicates the AUTOC-AR application is considered to have adopted the user experience approach both in terms of interaction and visualization application interface. Applications that have been developed can also support the concept of work safety. The recommended future work is to increase the 3D object of the car and keep it by existing car brands, so it is not far different from the actual form, then to evaluate the AUTOC-AR application with other testing methods and develop it further with Virtual Reality (VR) technology along with other enhancements to enrich interaction.

\section{REFERENCES}

[1] R. Azuma, "A Survey of Augmented Reality," Presence Teleoperators Virtual Environ., vol. 6, no. 4, 1997.

[2] Z. Feng, B. D. Henry, and B. Mark, "Trends in Augmented Reality Tracking, Interaction, and Display: A Review of Ten Years of ISMAR," Nanyang Technological University, Singapore, 2008.

[3] H. Tolle, A. Pinandito, E. M. A. Jonemaro, and K. Arai, "Virtual Reality Game Controlled with User's Head and Body Movement Detection Using Smartphone Sensors," ARPN J. Eng. Appl. Sci., vol. 10, no. 2, pp. 9776-9782, 2015.

[4] A. A. Syahidi, H. Tolle, A. A. Supianto, and K. Arai, "BandoAR: Real-Time Text-Based Detection System Using Augmented Reality for Media Translator Banjar Language to Indonesian with Smartphone," in Proceeding of the 5th IEEE ICETAS, 2018, pp. 1-6.

[5] A. Gladston and A. Duraisamy, "Augmented Reality Indoor Navigation Using Handheld Devices," Int. J. Virtual Augment. Real., vol. 3, no. 3, pp. 1-17, 2019. 
[6] A. A. Syahidi, H. Tolle, A. A. Supianto, and K. Arai, "AR-Child: Analysis, Evaluation, and Effect of Using Augmented Reality as a Learning Media for Preschool Children," in Proceeding of the 5th IEEE ICCED, 2019, pp. 1-6.

[7] P. B. Herlandy, J. A. Amien, P. Pahmi, and A. Satria, "A Virtual Laboratory Application for Vocational Productive Learning Using Augmented Reality," $J$. Pendidik. Teknol. dan Kejuru., vol. 25, no. 2, pp. 194-203, 2019.

[8] A. Suryanto, D. A. Kusumawati, and I. M. H. Sanhoury, "Development of Augmented Reality Technology Based Learning Media of Lathe Machines," $J$. Pendidik. Teknol. dan Kejuru., vol. 24, no. 1, pp. 32-38, 2018, doi: 10.21831/JPTK.V24I1.18245.

[9] M. E. Ismail et al., "The Effect of an Augmented Reality Teaching Kit on Visualization, Cognitive Load and Teaching Styles," J. Pendidik. Teknol. dan Kejuru., vol. 24, no. 2, pp. 178-184, 2018.

[10] R. S. Pressman, Software Engineering A Practitoner's Approach (Seventh Edition). New York: The McGraw-Hill Companies, Inc., 2010.

[11] F. Manuri and A. Sanna, "A Survey on Applications of Augmented Reality," ACSIJ Adv. Comput. Sci. an Int. J., vol. 5, no. 1, p. 19, 2016.

[12] T. Murnane and K. Reed, "On the Effectiveness of Mutation Analysis as a Black Box Testing," in Australian Software Engineering Conferen, 2001, pp. 12-20.

[13] S. Nidhra, "Black Box and White Box Testing Techniques - A Literature Review," Int. J. Embed. Syst. Appl., vol. 2, no. 2, 2012.
[14] E. Steegmans et al., "Black and White Testing: Bridging Black Box Testing and White Box Testing," J. Softw. Test., pp. 1-12, 2004.

[15] G. Allanwood and P. B. Beare, User Experience Design: Creating Design Users Really Love. London: Bedford Square, 2014.

[16] B. Laugwitz, M. Schrepp, and T. Held, "Construction and Evaluation of a User Experience Questionnaire," A. Holzinger USAB 2008, LNCS, vol. 5298, pp. 6367, 2008.

[17] M. P. Cota, J. Thomaschewski, M. Schrepp, and R. Goncalves, "Efficient Measurement of the User Experience," in Procedia Computer Science the 5th International Conference on Software Development and Technologies for Enhancing, 2014, pp. 491-498.

[18] M. Schrepp, A. Hinderks, and J. Thomaschewski, "Design and Evaluation of a Short Version of the User Experience Questionnaire (UEQS)," Int. J. Interact. Multimed. Artif. Intell., vol. 4, no. 6, pp. 103-108, 2017.

[19] M. Schrepp, User Experience Questionnaire Handbook Version 7. The UEQ, 2019.

[20] A. Moural and T. A. Oritsland, "User Experience in Mobile Virtual Reality: An On-site Experience," J. Digit. Landsc. Archit., vol. 4, p. '152-159, 2019.

[21] D. M. Yulanto, P. Sudira, and P. D. Aristya, "Quality Continuous Professional Development for Automotive Engineering Productive Teachers," J. Pendidik. Teknol. dan Kejuru., vol. 24, no. 2, pp. 192-197, 2018. 